\title{
SZOKI POLITYKI FISKALNEJ I MONETARNEJ JAKO PRZEDMIOT BADAŃ MAKROEKONOMII GOSPODARKI OTWARTEJ
}

\section{Wprowadzenie. Postawienie problemu}

Szeroko rozumiana globalizacja stworzyła nowe uwarunkowania działania i skuteczności podejmowanej przez państwa narodowe polityki makroekonomicznej. Dotyczy to zarówno polityki monetarnej realizowanej przez banki centralne, jak i polityki fiskalnej. Zarówno jedna, jak i druga, mimo iż pozostają domeną niezależnych działań władz publicznych poszczególnych krajów (z wyjątkiem krajów zintegrowanych w unii monetarnej, tj. strefie euro, które instytucjom ponadnarodowym oddały decyzje w sferze pieniężnej), muszą być podejmowane w warunkach otwartości gospodarek implicite w warunkach postępującej współzależności gospodarek i rynków krajowych powiązanych całym zespołem kanałów wzajemnych oddziaływań.

Szczególnym uwarunkowaniem dla skuteczności polityki gospodarczej jest międzynarodowa integracja rynków finansowych wraz z niezwykle dynamicznym przepływem kapitału finansowego w skali świata. Współzależności polityki monetarnej ze światowymi rynkami finansowymi są oczywiste i jednoznaczne: banki centralne są aktywnymi graczami i „aktorami” na światowych rynkach, emitują obligacje rządowe skierowane również do zagranicznych inwestorów, których rentowność zależna jest od pozycji ratingowej kraju ocenianej i ogłaszanej przez światowe agencje ratingowe, w swojej polityce biorą pod uwagę poziom kursów walutowych determinowany przez zagraniczne rynki, wreszcie ustalana przez nie wysokość stopy procentowej i podaży pieniądza wpływa na kurs realny pieniądza krajowego. Jeśli zaś chodzi o zależność efektów polityki fiskalnej od uwarunkowań związanych z międzynarodową integracją finansową, to temat jest o wiele bardziej złożony. Polityka fiskalna bowiem, podobnie jak monetarna, jest z jednej strony zależna od impulsów zewnętrznych, a z drugiej stanowi ich źródło, ale natura tych współzależności nie ma charakteru bezpośredniego i dlatego trudniejszy do uchwycenia na drodze analizy empirycznej. 
Spojrzenie na obydwa rodzaje polityki - politykę fiskalną i pieniężną - jako przedmiot badań makroekonomii gospodarki otwartej należy ująć w dwóch perspektywach. Po pierwsze, obydwie sfery oddziaływań makroekonomicznych mają swoje zagraniczne, tj. międzynarodowe efekty. Po drugie, w warunkach globalizacji podlegają one silnemu wpływowi zewnętrznych oddziaływań ekonomicznych. Wynika z tego, że skutki i efektywność zarówno polityki fiskalnej, jak i monetarnej zależne są nie tylko od wewnętrznych uwarunkowań makroekonomicznych i endogenicznych mechanizmów zachodzących w ramach rynków krajowych, ale również od faktu ich „wystawienia” i podatności na zewnętrzne, międzynarodowe oddziaływania realizujące się różnymi drogami i za pośrednictwem różnych procesów.

Szczególne znaczenie ma tu fakt istnienia międzynarodowej transmisji impulsów koniunkturalnych, która poddaje „weryfikacji” ostateczną skuteczność tzw. szoków monetarnych i fiskalnych, czyli odpowiednio stosowanych przez banki centralne instrumentów pieniężnych oraz podejmowanych przez rządy posunięć fiskalnych (i używanych do ich realizacji narzędzi). Należy przy tym zaznaczyć, iż o ile słowo „szok” w potocznym rozumieniu kojarzy się z nagłym, nieoczekiwanym i niepożądanym zdarzeniem, o tyle w słowniku ekonomicznym ${ }^{1}$ jest to zdarzenie silnie oddziałujące na gospodarkę - również celowe i zaplanowane, takie jak posunięcia polityki gospodarczej. Tymi rodzajami „szoków” zajmuję się w niniejszym opracowaniu.

Celem opracowania jest ogólna prezentacja problematyki szoków polityki fiskalnej i pieniężnej jako przedmiotu badań na polu makroekonomii gospodarki otwartej. Autorka rozumie przez to umieszczenie szoków w kontekście badawczym warunków „otwartości gospodarek”, co we współczesnych realiach oznacza de facto „warunki globalizacji”'. Z uwagi na ograniczoną objętość opracowania skupiono się na wybranych aspektach tej bardzo szerokiej problematyki.

Po pierwsze, zaprezentowano definicje szoków polityki fiskalnej i pieniężnej istniejące w literaturze makroekonomicznej. Po drugie, przypomniano podstawowe schematy koncepcyjne dotyczące efektów posunięć (szoków) polityki fiskalnej i pieniężnej, odwołując się w tym zakresie do hicksowskiego schematu IS-LM oraz do modelu małej otwartej gospodarki. Rozważania na temat małej otwartej gospodarki są punktem wyjścia do przypomnienia fundamentalnego jeśli chodzi o badanie przenoszenia efektów polityki makroekonomicznej między krajami modelu

\footnotetext{
1 Zwłaszcza bazując na literaturze angielskojęzycznej na temat polityki gospodarczej, jeśli bezpośrednio przetłumaczymy słowa monetary shock oraz fiscal shock i odniesiemy się do ich znaczenia w światowej literaturze ekonomicznej.

2 Por. np. V.K. Aggarwal, Economics: International Trade, w: Managing Global Issues: Lessons Learned, red. P.J. Simmons, C. de Jonge Oudraat, Carnegie Endowment for International Peace, Washington, D.C. 2001; A. Surdej, Współzależność gospodarcza a autonomia polityki gospodarczej państw, http://www.sporyokapitalizm.pl/
} 
Mundella-Fleminga (M-F). Opisany w modelu schemat skutków polityki fiskalnej i pieniężnej w różnych reżimach kursowych stał się na wiele lat bazą dla rozwoju badań i udoskonalania metod analizy międzynarodowych efektów polityki gospodarczej w warunkach gospodarki otwartej. Bezpośrednio lub w licznych rozwinięciach i modyfikacjach, bardziej zbliżających założenia pierwotnej wersji do dzisiejszych zależności, tendencji i przepływów makrogospodarki, model Mundella-Fleminga można odnaleźć również w najnowszych analizach gospodarki światowej. W opracowaniu skrótowo pokazałam ewolucję modelu w sensie koncepcyjnym (tj. nowe ujęcia, nowe założenia uzupełniające podstawowy schemat), ale też aplikacyjnym (wpisywanie go do nowoczesnych narzędzi analitycznych, przechodzenie od ujęcia statycznego do metod dynamicznych itp.). Szczególnie istotne jest wykorzystywanie wybranych wątków modelu Mundella-Fleminga do analiz bazujących na rozbudowanych modelach służących obecnie badaniu i prognozowaniu rozwoju gospodarki światowej, takich jak Multimod, opracowany i stosowany przez Międzynarodowy Fundusz Walutowy (IMF), INTERLINK OECD (lata 80. i 90.) czy New Global Model OECD (pierwsza dekada XXI w. i obecnie).

Skupiając się na wybranych aspektach tytułowej tematyki, w niniejszym opracowaniu abstrahuję od szerokiej podbudowy teoretycznej, jaką są poglądy poszczególnych nurtów i szkół ekonomii co do efektów polityki fiskalnej i pieniężnej oraz od szerokiej dyskusji na ten temat na polu rozwoju myśli ekonomicznej. Poglądy na obydwa rodzaje polityki reprezentowane chociażby wśród szkół tzw. głównego nurtu, a więc keynesizmu, monetaryzmu, nowej szkoły klasycznej, realnego cyklu koniunkturalnego, nowej szkoły keynesowskiej, szkoły austriackiej czy ekonomicznej teorii polityki, w tym na skuteczność pochodzących z nich szoków dla sterowania gospodarką, są bowiem w wielu punktach skrajnie odmienne ${ }^{3}$. Ja natomiast

3 Różnice w poglądach na temat siły oddziaływania (skuteczności) poszczególnych rodzajów polityki mają wiele aspektów. Jednym $\mathrm{z}$ nich są różne postulowane poziomy wrażliwości poszczególnych zmiennych makroekonomicznych na oddziaływanie narzędzi polityki gospodarczej (tj. w ogólności wydatków rządowych i stóp procentowych). Przykładem może być zasadniczy spór między keynesistami a monetarystami co do położenia krzywych zagregowanej podaży i zagregowanego popytu. Według keynesistów krzywa podaży jest płaska, a więc ekspansja, czy to fiskalna, czy monetarna, powoduje duży wzrost produkcji przy niewielkim podniesieniu cen (a polityka kontrakcyjna wywołuje duże spadki produkcji, ale również ze słabym wpływem na ceny). Według monetarystów zaś krzywa podaży jest stroma, co implikuje odwrotne efekty - tzn. stosowane narzędzia polityki fiskalnej i pieniężnej nie mają wpływu na poziom dochodu, ale przyczyniają się do podnoszenia lub obniżki cen). W związku z tym polityka gospodarcza może być skutecznym narzędziem do walki z inflacją. Mimo tych istotnych różnic trzeba ogólnie stwierdzić, że rozumowanie monetarystów i keynesistów rozgrywa się w zbliżonych ramach logicznych i analitycznych. Odmienne podejście do analizowania zjawisk ekonomicznych zaprezentowali natomiast zwolennicy innych szkół, np. nowej ekonomii klasycznej. Różnice w poglądach poszczególnych szkół na temat uwarunkowań funkcjonowania polityki gospodarczej dotyczą też takich istotnych kwestii, jak neutralność/brak neutralności pieniądza, celowość prowadzenia polityki stabilizacyjnej, istnienie racjonalnych oczekiwań lub ich brak, ramy czasowe analizy i inne. 
koncentruję się raczej na rozwoju ujęcia modelowego (ewolucja metody badawczej) w opisie szoków polityki fiskalnej i pieniężnej, ze szczególnym uwzględnieniem nowoczesnego podejścia ilościowego. Z przeglądu studiów empirycznych wynika zaś, że większość współczesnych badaczy mniejszą wagę przywiązuje do kwestii, czy wnioski z ich analizy potwierdzają taką czy inną teorię, mogą być przypisane lub mieszczą się w ramach danego nurtu ekonomii (jedynie w przyjmowanych założeniach budowanych modeli znajdujemy odwołania do poglądów danej szkoły, np. keynesowskiej, monetarystycznej czy nowej ekonomii klasycznej). Nowoczesne podejście do badania szoków polityki fiskalnej i pieniężnej opiera się obecnie na wykorzystywaniu zaawansowanych metod analizy danych, jak modele autoregresyjne (VAR) czy stochastyczne dynamiczne modele równowagi ogólnej (DSGE), o czym szerzej napiszę w opracowaniu.

\section{Definicja szoków polityki fiskalnej i pieniężnej w literaturze przedmiotu}

Przegląd literatury przedmiotu, stosowanych podejść, metod i danych każe twierdzić, że zarówno szok polityki fiskalnej, jak i szok polityki monetarnej to ściśle określone w czasie działanie podjęte przez odpowiednie instytucje odpowiedzialne za daną sferę krajowej polityki makroekonomicznej. Obydwa rodzaje szoków należą do kategorii szoków popytowych, a więc o krótkookresowym oddziaływaniu na gospodarkę, w odróżnieniu od szoków podażowych o długotrwałym wpływie na wielkość produkcji i poziom cen. Działania te są źródłem impulsów dla danych sfer gospodarowania, konkretnych gałęzi lub dla kondycji ekonomicznej całego kraju: dodatnich w przypadku polityki ekspansywnej lub ujemnych, gdy mamy do czynienia z restrykcjami nakierowanymi na "schładzanie” koniunktury, obniżanie tempa wzrostu cen etc. W tym sensie, jak już wspomniano, w kategoriach czysto semantycznych, „szok”, o jakim mówię, nie jest utożsamiany z nagłym wstrząsem i odbiega znaczeniowo od szoków np. na giełdach, takich jak nagłe i błyskawicznie rozprzestrzeniające się spadki kursów akcji, objawy paniki wśród inwestorów, ucieczka od inwestycji w danym regionie i inne.

W tym miejscu warto choćby pobieżnie przyjrzeć się, jakie zmienne stosowane są w literaturze jako denotujące szoki polityki monetarnej i fiskalnej. Jeśli chodzi o te pierwsze, pokazywane są one $\mathrm{z}$ reguły poprzez (nagłe) zmiany poziomu stóp procentowych banku centralnego (stopa referencyjna, dyskontowa, stopa oprocentowania pożyczek udzielanych przez bank centralny jako kredytodawcę ostatniej instancji, 
stopa rezerw obowiązkowych etc., w zależności od narzędzi stosowanych przez banki centralne i instytucje władzy monetarnej analizowanych krajów). Szoki monetarne to więc przede wszystkim zmiany i wahania wysokości nominalnych stóp procentowych (z konsekwencjami w postaci wahań realnych krótkookresowych kursów walutowych), rzadziej stosowane są dane na temat zmian poziomu bazy monetarnej (podaży pieniądza), w analizach w przekroju wielu krajów trudniej bowiem o jednolite dane do analiz empirycznych (różnie skonstruowane są agregaty pieniężne).

W literaturze polskiej szoki w polityce monetarnej definiowane są przykładowo przez D. Serwę i M. Szymańską jako zmiany poziomu stopy referencyjnej - zmiany poziomu tej stopy, określając bieżący kierunek polityki pieniężnej, mają za zadanie bezpośrednio oddziaływać na międzybankowy rynek pieniężny, a poprzez niego na sytuację makroekonomiczną w kraju. Innymi badaczami analizującymi szoki polityki monetarnej są m.in. B. Bernanke i I. Mihov', E. Leeper i inni' ${ }^{6}$, L.J. Christiano i inni ${ }^{7}$, C. Favero ${ }^{8}$, M. Eichenbaum i Ch.L. Evans ${ }^{9}$, C.A. Sims ${ }^{10}$, J.D. Hamilton i A.M. Herrera ${ }^{11}$ czy S. Kim ${ }^{12}$.

O ile istnieje w literaturze zgoda co do tego, że szoki polityki monetarnej (monetary policy shocks) to głównie nagłe zmiany (wzrosty) stopy procentowej, o tyle istnieje co najmniej kilka różnych definicji szoku fiskalnego. Dwa podstawowe rodzaje szoków polityki fiskalnej to szok wydatków rządowych (government spending shock), definiowany jako sytuacja, w której wydatki wzrastają w pewnym ściśle określonym czasie po szoku lub też ulegają nagłemu obniżeniu, i szok dochodów budżetowych (government revenue shock) ${ }^{13}$, związany z cięciami lub podwyższeniem podatków.

4 Por. D. Serwa, M. Szymańska, Reakcje rynków finansowych na szoki w polityce pieniężnej, „Bank i Kredyt" czerwiec 2004, nr 1.

5 B.S. Bernanke, I. Mihov, Measuring Monetary Policy, „NBER Working Paper” 1995, No. 5145.

6 E. Leeper, Ch. Sims, T. Zha, What Does Monetary Policy Do?, „Brookings Papers on Economic Activity" 1996, No. 2, s. 1-63.

7 L.J. Christiano, M. Eichenbaum, Ch.L. Evans, Monetary policy shocks: What have we learned and to what end?, w: Handbook of Macroeconomics, red. J.B. Taylor \& M. Woodford, Vol. 1, Ch. 2, Elsevier 1999, s. 65-148.

8 C.A. Favero, How do European Monetary and Fiscal Authorities Behave?, „CEPR Discussion Papers” 2002, No. 3426.

9 M. Eichenbaum, Ch.L. Evans, Some Empirical Evidence on the Effects of Monetary Policy Shocks on exchange Rates, „NBER Working Paper” 1993, No. 4271.

$10 \mathrm{Ch}$.A. Sims, Interpreting the macroeconomic time series facts: The effects of monetary policy, „European Economic Review" June 1992, Vol. 36, Issue 5, s. 975-1000.

${ }^{11}$ J.D. Hamilton, A.M. Herrera, Oil Shocks and Aggregate Macroeconomic Behavior: The Role of Monetary Policy, „Journal of Money, Credit and Banking” April 2004, Vol. 36, No. 2, s. 265-286.

12 S. Kim, Do monetary policy shocks matter in the G-7 countries? Using common identifying assumptions about monetary policy across countries, „Journal of International Economics” August 1999, Vol. 48, Issue 2, s. $387-412$

13 Por. O. Blanchard, R. Perotti, An Empirical Characterization of the Dynamic Effects of Changes in Government Spending and Taxes on Output, „Quarterly Journal of Economics” 2002, No. 1329-1368, s. 3. 
Wielu autorów uważa przy tym, że skoro jedne i drugie wpływają na PKB, to należy łączyć je w analizie empirycznej. Wydatki rządowe i podatki (w badaniach empirycznych ujęte w określone zmienne) są bowiem współzależne, więc dla właściwej i wyczerpującej oceny wpływu jednej z nich na gospodarkę w większości studiów empirycznych do analizy włącza się (uwzględnia się) również tę drugą.

Formalnie rzecz biorąc, szoki dodatnie są zawsze związane ze wzrostem wartości danej zmiennej (np. dodatni szok podatkowy to wzrost podatków, a dodatni szok wydatkowy to ekspansja w wydatkach rządowych). Badania empiryczne zawierają zazwyczaj dokładne, niebudzące wątpliwości co do zakładanego kierunku wpływu zmiennych na PKB wyjaśnienia definicyjne z podaniem dokładnego opisu zastosowanych mierników, źródeł danych etc. Jak zauważają A. Mountford i H. Uhlig ${ }^{14}$, szok polityki fiskalnej to „zaskakująca zmiana w tej polityce, ale nie ma czegoś takiego jak szok polityki fiskalnej per se". Ta domena działań państwa obejmuje bowiem ogromne spektrum najróżniejszych celów, posunięć i narzędzi; mamy niekończącą się listę różnych rodzajów wpływów budżetowych, dla których uzyskania mogą być zmienione zasady podatkowe, najróżniejsze kategorie wydatków budżetowych, różne kombinacje w ramach tax-debt dla finansowania danego strumienia wydatków rządowych czy warianty wydatków dla określonego poziomu długu. Dlatego często w badaniach przyjmuje się, że szoki omawianego typu to po prostu dane efekty wpływu zagregowanych zmiennych fiskalnych na gospodarkę w skali makro.

Idąc za rozumowaniem przyjmowanym przez większość autorów, same „szoki” $\mathrm{w}$ polityce fiskalnej związane są z działaniami dyskrecjonalnymi, a więc $\mathrm{z}$ aktywnym wykorzystywaniem odpowiednich instrumentów (zmiany w podatkach, wydatkach rządowych czy transferach) do wpływania na sytuację makroekonomiczną kraju, w odróżnieniu od zwykłego funkcjonowania automatycznych stabilizatorów koniunktury (tj. polityki pasywnej), jak np. płatności transferowe, import w gospodarce otwartej czy stopy podatkowe, które mają za zadanie automatyczne łagodzenie wahań i zmniejszanie amplitudy krajowego cyklu koniunkturalnego ${ }^{15}$. Odpowiednia identyfikacja zmiennych denotujących szoki polityki fiskalnej jest więc utrudniona, gdyż zmiany w wydatkach rządowych i podatkach często odzwierciedlają antycykliczne działania budżetowe podejmowane w celu stabilizowania gospodarki lub też dążenia rządu do utrzymywania deficytu budżetowego i długu publicznego na określonym

14 A. Mountford, H. Uhlig, What are the Effects of Fiscal Policy Shocks?, „NBER Working Paper” December 2008, No. 14551, s. 4.

${ }^{15}$ Inną sprawą jest, że większa progresywność systemu podatkowego może wzmocnić efekty automatycznych stabilizatorów. Przykładowo A. Mountford i H. Uhlig w swoim badaniu starają się odfiltrować faktyczne zmiany fiskalne od automatycznych reakcji fiskalnych zmiennych na szoki cyklu koniunkturalnego i szoki polityki monetarnej. Por. ibidem, s. 1. 
poziomie. Jednocześnie znaczny ułamek dochodów państwa zmienia się automatycznie $\mathrm{z}$ dochodem i z tego powodu jest łatwy do przewidzenia. Trudności i kontrowersje co do wykorzystywanych w analizach mierników dyskrecjonalnej polityki fiskalnej podkreślają m.in. H. Bouakez i inni ${ }^{16}$. Według nich dla znalezienia właściwych miar szoków fiskalnych istotne jest poczynienie implicite lub explicite odpowiednich założeń umożliwiających identyfikację egzogenicznych i nieoczekiwanych zmian w podatkach i wydatkach budżetowych, które to są właściwymi „szokami fiskalnymi” - a więc niebędącymi efektem automatycznej odpowiedzi na zmiany koniunktury (automatycznymi stabilizatorami koniunktury). Autorzy ujmują to w następujący sposób: „zmiany w podatkach i wydatkach publicznych odzwierciedlają zarówno automatyczne/systematyczne odpowiedzi tych zmiennych na zmianę w warunkach makroekonomicznych kraju, jak i egzogeniczne, nieoczekiwane zmiany w polityce, które to są szokami polityki fiskalnej” ${ }^{17}$. Jednocześnie założenia co odpowiedniego „wyłuskania” zmiennych mają często charakter arbitralny. Wielu autorów identyfikuje szoki fiskalne poprzez robienie a priori założeń co do reakcji konkretnych zmiennych na działanie tych szoków, np. O. Blanchard i R. Perotti ${ }^{18}$, J. Gali i inni ${ }^{19}$. Często bierze się za podstawę informacje instytucjonalne na temat systemu podatkowego czy szczegółowe dane historyczne z uwzględnieniem okresów reform, kalendarza wyborów politycznych (W. Edelberg $\mathrm{i}_{\text {inni }}{ }^{20}$, C. Burnside ${ }^{21}$ ). Szoki podatkowe są identyfikowane np. poprzez odfiltrowanie tej części wpływów budżetowych, które zmieniają się automatycznie wraz z dochodem i poprzez przyjęcie, że wynikające z tego cyklicznie dostosowywalne podatki nie korespondują z bieżącymi, tj. szokowymi zmianami w podatkach.

Według A. Mountforda i H. Uhliga „należy również wziąć pod uwagę fakt rozbieżności w czasie pomiędzy ogłoszeniem a implementacją narzędzi polityki fiskalnej oraz to, że samo ogłoszenie przez rząd określonych planów budżetowych może spowodować przesunięcia w zmiennych makroekonomicznych, zanim de facto nastąpi wprowadzenie ich w życie"22. Jest to podnoszona w teorii makroekonomii, zwłaszcza

16 Por. H. Bouakez, F. Chihi, M. Normandin, Measuring the Effects of Fiscal Policy, January 2009, s. 3-4, https://www.gate.cnrs.fr/IMG/pdf/Normandin_Dec_2009.pdf

17 Por. ibidem.

18 O. Blanchard, R. Perotti, op.cit.

19 J. Gali, J. Lopez-Salido, J. David, J. Valles, Understanding the Effects of Government Spending on Consumption, „Journal of the European Economic Association” 2007, No. 5(1), s. 227-270.

${ }^{20}$ W. Edelberg, M. Eichenbaum, J.D.M. Fisher, Understanding the Effects of a Shock to Government Purchases, „Review of Economic Dynamics” 1999, No. 2, s. 166-206.

${ }^{21}$ C. Burnside, M. Eichenbaum, J. Fisher, Fiscal Shocks And Their Consequences, „NBER Working Paper” 2003, No. 9772.

22 O. Blanchard i R. Perotti nazywają to,,efektem ogłoszenia" (announcement effect), który według tych autorów oznacza, że „aktualny szok polityki fiskalnej wpływa na wartości zmiennych fiskalnych w przyszłości, ale nie w teraźniejszości”. Por. O. Blanchard, R. Perotti, op.cit., s. 8. 
przez przedstawicieli szkoły monetarystycznej ${ }^{23}$, kwestia opóźnień wewnętrznych polityki fiskalnej. Ma to związek z faktem, iż zazwyczaj wymaga czasu opracowanie, przygotowanie, a następnie wdrażanie samych posunięć fiskalnych. Dlatego, jak twierdzą niektórzy ekonomiści, polityka ta nie może w ogóle być stosowana jako narzędzie interwencji, przy niebezpieczeństwie wręcz wywołania skutków odwrotnych od zamierzonych (np. ucieczka do szarej strefy i przeprofilowanie bilansów w celu uniknięcia zapowiadanych wyższych podatków, widoczne w wymiernych liczbowych zmianach w ramach zmiennych fiskalnych ${ }^{24}$.

W badaniach wykorzystuje się różne dane i wskaźniki jako szoki fiskalne, tj. wydatków rządowych i podatków. O. Blanchard i R. Perotti przykładowo definiują zmienną "dochód rządowy" jako całkowite wpływy podatkowe minus transfery (łącznie z odsetkami), nazywając to "podatki netto”. Zmienną „wydatki” definiują jako całkowite rządowe zakupy dóbr i usług, tj. „konsumpcja rządowa” plus rządowe inwestycje, nazywając to „wydatkami rządowymi (government expenditures). Następnie badają efekty wpływu tego rodzaju szoków podatkowych i wydatkowych na aktywność makroekonomiczną w USA w całym okresie powojennym (bazują na instytucjonalnych statystykach na temat systemów podatkowych i transferowych).

A. Mountford i H. Uhlig z kolei zajmują się trzema rodzajami szoków fiskalnych, jakimi są: ekspansja fiskalna finansowana deficytem, finansowane deficytem cięcia podatkowe oraz ekspansja zbilansowanego budżetu (balanced budget spending expansion), bazując na danych kwartalnych dla USA z lat 1955-200025. Na marginesie warto dodać, że według przeprowadzonej przez autorów analizy drugi z wymienionych scenariuszy „działa” najskuteczniej w kierunku zwiększenia PKB, a to dzięki osiągnięciu najwyższego mnożnika wartości zaktualizowanej (prezent value multiplier), tj. 5 USD dodatkowego PKB wygenerowanego przez jednodolarowe całkowite cięcie w dochodach budżetowych w okresie 5 lat od wystąpienia szoku.

H. Bouakez i inni przeprowadzają badanie dla oceny makroekonomicznych efektów szoków polityki fiskalnej w USA przed i po 1979 r. na podstawie danych z lat 1960-2007. Szoki dotyczą wydatków budżetowych definiowanych jako suma wydatków federalnych (łącznie z wydatkami na obronę), konsumpcji rządowej oraz wydatków federalnych na inwestycje w środki trwale, podatki natomiast to całkowite wpływy do kasy państwowej minus płatności transferowe netto.

\footnotetext{
${ }^{23}$ Tego rodzaju obserwacje skłoniły monetarystów do twierdzenia o nieskuteczności dyskrecjonalnej polityki fiskalnej i propagowania stosowania raczej automatycznych stabilizatorów koniunktury.

${ }^{24}$ Szerokie omówienie kontrowersji wokół efektywności polityki fiskalnej znajdujemy m.in. w opracowaniu M. Gajdy-Kantorowskiej. Por. M. Gajda-Kantorowska, Analiza przydatności polityki fiskalnej do usuwania skutków kryzysu w krótkim, średnim i dtugim okresie, w: Polityka makroekonomiczna w warunkach kryzysu i jej wpływ na gospodarke, red. Z. Dach, Oficyna Wolters Kluwer business, Warszawa 2011, s. 84-98.

${ }_{25}$ A. Mountford, H. Uhlig, op.cit., s. 4.
} 
Na temat szoków polityki fiskalnej i ich efektów istnieje bogata literatura. Wśród wielu pozycji wymienić można opracowania autorstwa A. Fatása i I. Mihova ${ }^{26}$, J. Gali i innych ${ }^{27}$, C. Burnside'a i innych ${ }^{28}$, C. Caldara i Ch. Kampsa ${ }^{29}$, C. Cavallo ${ }^{30}$, G.B. Wolffa i innych ${ }^{31}$ czy P. Burriela ${ }^{32}$.

\section{Szoki polityki fiskalnej i pieniężnej we współczesnych gospodarkach otwartych - członkostwo w ugrupowaniach integracyjnych a perspektywa ogólna}

Jak zauważono we wstępie opracowania, spojrzenie na obydwa rodzaje polityki, tj. zarówno politykę fiskalną, jak i pieniężną jako przedmiot badań makroekonomii gospodarki otwartej należy ująć w dwóch perspektywach. Z jednej strony każda z nich zależna jest od szoków zewnętrznych, z drugiej - stanowi ich źródło. Rysują się tu dwa niezależne obszary problemowe i badawcze.

Po pierwsze, szoki polityki gospodarczej (i w ogóle polityka gospodarcza) są przedmiotem międzynarodowych współzależności, w przypadku gdy kraj jest członkiem międzynarodowego porozumienia gospodarczego o charakterze handlowym, walutowym itp. Problematyka zależności polityki fiskalnej i pieniężnej od makroekonomicznych wpływów ze strony innych państw w sytuacji udziału danego kraju w międzynarodowym ugrupowaniu integracyjnym jest bardzo rozległa i wieloaspektowa i jako taka stanowi obszar wielu studiów.

Wpływ zewnętrznego otoczenia ekonomicznego na politykę gospodarczą, co de facto dotyczy wpływu otwartości czy szerzej globalizacji na gospodarkę w ogóle,

26 A. Fatás, I. Mihov, The Effects of Fiscal Policy on Consumption and Employment: Theory and Evidence, manuscript, INSEAD 2001; A. Fatás, I. Mihov, Government size and automatic stabilizers: international and intranational evidence, „Journal of International Economics” October 2001, Vol. 55, Issue 1, s. 3-28; A. Fatás, I. Mihov, The macroeconomic effects of fiscal rules in the US states, "Journal of Public Economics" January 2006, Vol. 90, Issues 1-2, s. 101-117; A. Fatás, I. Mihov, The Euro and Fiscal Policy, w: Europe and the Euro, red. A. Alesina, F. Giavazzi, NBER, University of Chicago Press 2010, s. 287-324.

27 J. Gali, D. Lopez-Salido, J. David, op.cit., s. 227-270.

${ }^{28}$ C. Burnside, M. Eichenbaum, J.D.M. Fisher, op.cit., s. 89-117.

${ }^{29}$ D. Caldara, Ch. Kamps, What are the Effects of Fiscal Policy Shocks? A VAR-based Comparative Analysis, „ECB Working Paper” March 2008, No. 877.

30 C. Cavallo, Government employment expenditure and the effects of fiscal policy shocks, „Federal Reserve Bank of San Francisco Working Paper Series, Working Paper" 2005, No. 16.

${ }^{31}$ G.B. Wolff, J. Tenhofen, K.H. Heppke-Falk, The macroeconomic effects of exogenous fiscal policy shocks in Germany: a disaggregated SVAR analysis, „Discussion Paper Series”, „VolkswirtschaftlichesForschungszentrum der Deutschen Bundesbank" 2006, No. 41.

32 P. Burriel, F. De Castro, D. Garrote, E. Gordo, J. Paredes, J.P. Pérez, Fiscal Policy Shocks in the Euro Area and the US: An Empirical Assessment, „Fiscal Studies” June 2010, Vol. 31, Issue 2, s. 251-285. 
a w tym na skutki polityki gospodarczej, może wiązać się zarówno ze wzmacnianiem, jak i osłabianiem efektów wszelkiego rodzaju szoków pochodzących z kraju (country-specific). W przypadku formalnych uregulowań prawnych, np. dotyczących liberalizacji wymiany towarów i usług, inwestycji, przepływu pracowników, przepływów finansowych etc., występujących w związku z podpisaniem przez kraj międzynarodowej umowy, porozumienia, wejściem do regionalnego ugrupowania integracyjnego, strefy wolnego handlu etc., makroekonomiczny wpływ otoczenia jest jednoznaczny. Problematyka makroekonomicznych skutków formalnych uregulowań „otwierających” gospodarkę, w tym: krajową politykę gospodarczą na wpływ reszty świata, jest szeroka i wymaga podjęcia odrębnych studiów literaturowych. W związku z tym w niniejszym opracowaniu nie będę poświęcać jej więcej miejsca, skupiając się na ewolucji w ujęciach modelowych w zakresie tytułowego zagadnienia.

\section{Szoki polityki fiskalnej i pieniężnej w badaniach - ujęcie modelowe i analityczne}

\subsection{Szoki polityki fiskalnej i pieniężnej w gospodarce otwartej - ujęcie keynesowskie}

Prezentacja teorii na temat szoków polityki gospodarczej w warunkach otwartości gospodarek nie jest sprawą łatwą, gdyż de facto łączy w sobie z jednej strony elementy wiedzy na temat wpływu impulsów fiskalnych oraz monetarnych na makrogospodarkę, z drugiej - koncepcje dotyczące międzynarodowych współzależności, jak np. transmisja szoków między krajami. Z uwagi na objętość opracowania uproszczę tę problematykę, odwołując się do wybranych rudymentarnych koncepcji, na których bazuje przekaz akademicki, a które dały jednocześnie podstawę rozwoju badań na polu tytułowej problematyki. Mam tu na myśli przede wszystkim standardowy model Hicksa IS-LM, również odwołujący się do keynesowskiej tożsamości dochodu model małej otwartej gospodarki, a także model Mundella-Fleminga (M-F), który stricte dotyczy skutków polityki gospodarczej wraz z późniejszymi powstałymi na jego bazie koncepcjami rozwijającymi całość na rozważania międzynarodowe.

Powszechnie uznawany za podstawę rozważań na temat efektów polityki fiskalnej i pieniężnej schemat IS-LM stosowany był w głównej mierze przez keynesistów i przez nich wprowadzony do ścisłego nurtu makroekonomicznego dyskursu. Zgodnie z modelem (przy wszystkich innych standardowych założeniach, jak dodatnia zależność pomiędzy konsumpcją a dochodem rozporządzalnym i ujemna między stopą procentową i inwestycjami) szoki (posunięcia) polityki gospodarczej zmieniają PKB 
poprzez bezpośrednie oddziaływanie na wysokość stopy procentowej. Proekspansywne szoki polityki fiskalnej, mimo początkowego dodatniego wpływu na wysokość dochodu, przyczyniają się do podniesienia poziomu krajowych stóp procentowych i skutkiem tego - spadku eksportu netto i inwestycji (efekt wypierania). Prorestrykcyjna polityka budżetowa spowoduje natomiast spadek konsumpcji, ale nie ograniczy innych składowych PKB. Natomiast szoki ekspansywnej polityki monetarnej odnoszą dwojako pozytywny skutek - pobudzają PKB, ale też -poprzez obniżkę stóp procentowych - stymulują pozytywnie inwestycje i eksport netto (restrykcyjne szoki pieniężne hamują wzrost gospodarczy, również poprzez obniżenie krajowych inwestycji i eksportu netto). Jak należy jednak pamiętać, zależności te nie mają charakteru „absolutnego”, gdyż względna skuteczność posunięć w sferze polityki fiskalnej i pieniężnej (szoków) zależy od wrażliwości składników zagregowanego popytu (zwłaszcza inwestycji $I$ i exportu netto $X$ ) oraz elastyczności popytu na pieniądz względem zmian stopy procentowej ${ }^{33}$.

Szoki ekspansywnej polityki fiskalnej są skuteczne w stymulowaniu PKB, jeśli wrażliwość $I$ i $X$ na stopy jest niewielka (stroma krzywa IS) i stopy niewiele wzrastają oraz w przypadku wysokiej wrażliwości popytu na pieniądz na stopy procentowe (płaska LM): stopy muszą wtedy wzrosnąć niewiele, by pobudzony wzrostem PKB popyt na pieniądz zbalansował się powtórnie (dostosował) do niezmienionej podaży pieniądza. Szoki fiskalne nie stymulują dodatnio PKB w sytuacji odwrotnej - gdy mamy do czynienia ze znaczną elastycznością $I$ i $X$ względem zmian krajowych stóp rynkowych oraz niewielką wrażliwością popytu na pieniądz na stopy procentowe ${ }^{34}$.

Odwrotne niż w przypadku polityki budżetowej warunki sprzyjają względnej skuteczności krajowej polityki monetarnej. Proekspansywne szoki silnie dodatnio wpływają na dochód narodowy w przypadku, gdy mamy do czynienia ze znaczną obniżką krajowych stóp procentowych i silnym pobudzeniem w następstwie tego inwestycji i eksportu netto w gospodarce (duża wrażliwość $I$ i $X$ na stopy procentowe, płaska krzywa IS). Drugim warunkiem sprzyjającym skuteczności polityki pieniężnej jest stroma LM, oznaczająca niską wrażliwość popytu na pieniądz na stopy (popyt na pieniądz musi dostosować się do podaży podniesionej w ramach posunięć polityki monetarnej, przy jego niskiej wrażliwości stopy „muszą” więc znacznie spaść ze wszystkimi tego dodatnimi konsekwencjami dla inwestycji i eksportu netto). Ekspansja monetarna będzie natomiast nieskuteczna w przypadku odwrotnym, tj. małej wrażliwości $I$ i $X$, natomiast dużej popytu na pieniądz na stopy procentowe.

33 Por np. N.G. Mankiw, Macroeconomics, $7^{\text {th }}$ ed., Worth Publishers, New York 2010; M. Burda, Ch. Wyplosz, Macroeconomics - A European Text, $5^{\text {th }}$ ed., Oxford University Press, Oxford 2009; R.E. Hall, J.B. Taylor, Makroekonomia - Teoria, funkcjonowanie i polityka, Wydawnictwo Naukowe PWN, Warszawa 1997.

34 Ibidem. 
Podstawy rozważań na temat szoków polityki gospodarczej w warunkach otwartości gospodarki krajowej - a więc przy założeniu istnienia jej szerokich współzależności z gospodarką świata oraz potencjalnej podatności na szoki zewnętrzne - ujmuje makroekonomiczny model „małej otwartej gospodarki”, odwołujący się też do zależności prezentowanych w modelu IS-LM.

Ten wyjściowy model oparty jest na standardowych założeniach otwartości: zakłada funkcjonowanie gospodarki w warunkach doskonałej mobilności kapitału (system płatności międzynarodowych, który umożliwia realizację transakcji bez ograniczeń dewizowych), doskonałe poinformowanie uczestników rynku i wynikający $\mathrm{z}$ tego mechanizm dostosowania krajowej stopy procentowej $(r)$ do stopy $\mathrm{w}$ „reszcie świata" $\left(r^{\star}\right)^{35}$. Co do strony podażowej, to produkcja określana jest przez nakład czynników produkcji.

Model określa stan bilansu handlowego kraju jako różnicę pomiędzy oszczędnościami a inwestycjami, co wynika z równania tożsamości dochodu w otwartej gospodarce i podstawowych zależności w jego ramach ${ }^{36}$. Oszczędności małej otwartej gospodarki są natomiast funkcją dochodu (dochodu rozporządzalnego), konsumpcji, wydatków budżetowych i podatków. Gdy wartość różnicy $S$ - I jest dodatnia (oszczędności krajowe przekraczają krajowe wydatki inwestycyjne), mamy do czynienia z odpływem kapitału netto (ujemna wartość różnicy między pożyczkami udzielanymi a zaciąganymi w „reszcie świata”) oraz z nadwyżką handlową. W przeciwnym wypadku mamy do czynienia z napływem kapitału finansowego z zagranicy (finansującego zakupy netto) oraz z deficytem handlowym („mała otwarta gospodarka" nie jest w stanie sfinansować inwestycji czy zakupu dóbr i usług zagranicą z własnych oszczędności). Stan bilansu handlowego małej otwartej gospodarki

35 Światowa stopa procentowa determinuje wysokość krajowych stóp procentowych z uwagi na fakt, że modelowa „mała otwarta gospodarka” stanowi niewielką „część” gospodarki globalnej, nie ma wpływu na światowe stopy procentowe i w związku z tym staje się jest niejako „biorcą” sytuacji w tym zakresie. Spełnione są też inne standardowe założenia, jak dodatnia zależność pomiędzy konsumpcją a dochodem rozporządzalnym i ujemna pomiędzy stopą procentową i inwestycjami. Wobec tego, że rezydenci mają doskonałą wiedzę na temat parametrów gospodarki (przy braniu pożyczek zawsze będą kierować się niższą stopą procentową, pożyczkodawcy będą pożyczać po jak najwyższej stopie) w warunkach doskonałego dostępu do światowych rynków finansowych i doskonałej informacji, działa stały mechanizm dostosowawczy krajowej stopy procentowej do poziomu światowego.

${ }^{36} \mathrm{Z}$ podstawowych zależności w ramach tożsamości dochodu dla gospodarki otwartej $Y=C+I+G+X$ oraz $Y=C+S+T+X$ (gdzie: $Y$ - dochód, $I$ - inwestycje, $C$ - konsumpcja, $T$ - podatki, $X$ - eksport netto, w uproszczeniu utożsamiany z bilansem handlowym) wiadomo, że $I+X=Y-C-G$. Z równań oszczędności całkowitych kraju $(S=S p+S g$ ) wynika, że $S=Y-C-G$, z czego mamy: $I+X=S$ (oszczędności krajowe mogą być przeznaczone na inwestycje wewnętrzne lub/i na zakup dóbr i usług za granicą $X$. Bilans handlowy równa się więc różnicy pomiędzy oszczędnościami i inwestycjami (tj. $\underline{S-I=X}$ ). Dla uzupełnienia dodajmy, że różnica po prawej stronie równania oznacza po prostu nadwyżkę oszczędności nad ich wykorzystaniem w kraju w postaci inwestycji (innymi słowy, wypływ netto kapitału), po prawej stronie mamy bilans handlowy. 
determinowany jest więc różnicą między krajowymi oszczędnościami a inwestycjami określanymi przez poziom światowej stopy procentowej. Każdy szok polityki gospodarczej, który podnosi oszczędności krajowe (lub obniża inwestycje) prowadzi do nadwyżki w handlu (szok obniżający oszczędności lub podnoszący inwestycje krajowe prowadzi do deficytu handlowego $)^{37}$.

Kluczową rolę w mechanizmie balansowania międzynarodowych przepływów kapitałowych odgrywa stopa procentowa reszty świata, determinująca stopę krajową. Wyższa światowa stopa procentowa $\left(r^{\star}\right)$ prowadzi do nadwyżki w bilansie handlowym kraju, niższa stopa procentowa (wyższe inwestycje krajowe) prowadzi do deficytu handlowego małej otwartej gospodarki. Natomiast obniżenie krajowej stopy działa (za sprawą kursu walutowego ${ }^{38}$ ) w kierunku nadwyżki w bilansie handlowym małej gospodarki (lub obniżenia deficytu); podwyższenie stóp procentowych w kraju wpływa na pogłębienie deficytu (zmniejszenie nadwyżki).

Przykładowo, ekspansywna polityka fiskalna „w kraju” (wzrost wydatków rządowych) wpływa (poprzez podwyższenie krajowej stopy procentowej) na obniżkę krajowych oszczędności ${ }^{39}$. Przy niezmienionej światowej stopie procentowej, pozostawiającej inwestycje małej otwartej gospodarki na wyjściowym poziomie (inwestycje muszą być finansowane pożyczkami z zagranicy), w efekcie następuje spadek eksportu netto (deficyt bilansu handlowego, jeśli punktem wyjścia był stan równowagi), napływ kapitału i obniżenie PKB. Szok restrykcyjnej polityki fiskalnej w kraju spowoduje zaś napływ kapitału i poprawę bilansu handlowego ${ }^{40}$.

Szok ekspansywnej polityki fiskalnej w reszcie świata (wzrost wydatków budżetowych w dużym kraju z punktu widzenia małej otwartej gospodarki) spowoduje wzrost światowej stopy procentowej oraz spadek „światowych” oszczędności. W warunkach zakładanej doskonałej mobilności kapitału i doskonałej informacji redukuje to pożyczki zaciągane przez małą otwartą gospodarkę na międzynarodowych rynkach finansowych. Spadają więc inwestycje w małej gospodarce, co przy niezmienionych oszczędnościach krajowych prowadzi do poprawy bilansu handlowego (nadwyżka jeśli za punkt wyjścia przyjmujemy równowagę, względnie redukcja deficytu handlowego $)^{41}$.

${ }^{37}$ N.G. Mankiw, op.cit.; M. Burda, Ch. Wyplosz, op.cit.

${ }^{38}$ Jeśli stopa proc. krajowa $(r)$ jest niższa niż zagraniczna $\left(r^{*}\right)$, to następuje odpływ kapitału, co implikuje spadek kursu waluty krajowej (deprecjacja), a w następstwie tego - wzrost eksportu i obniżenie importu (poprawa bilansu handlowego). W przeciwnym wypadku następuje napływ kapitału z zagranicy, aprecjacja kursu waluty małej otwartej gospodarki i pojawienie się deficytu handlowego.

${ }^{39}$ Szok polityki fiskalnej w postaci obniżenia podatków podwyższy konsumpcję i obniży oszczędności całkowite. Nawet jeśli część obniżki podatków przyczyni się do zwiększenia oszczędności krajowych, to i tak publiczne oszczędności spadną o całkowitą wartość obniżki podatków, a w efekcie - oszczędności spadną.

${ }^{40}$ N.G. Mankiw, op.cit.

41 Ibidem. 


\subsection{Model Mundella-Fleminga a ewolucja w analizie szoków polityki gospodarczej i ich międzynarodowych efektów}

Kanon rozważań na temat efektów polityki fiskalnej i pieniężnej w warunkach otwartości gospodarki stworzony został w modelu Mundella-Fleminga. Model stanowi rozwinięcie zależności modelu hicksowskiego o międzynarodowe przepływy kapitałowe, łącząc trzy warunki równowagi, tj. rynku dóbr (krzywa IS), rynku pieniądza (LM) i przepływu kapitału (tzw. krzywa równowagi bilansu płatniczego przebiegająca na poziomie światowej stopy procentowej). Rozpatruje on krótkookresowe efekty szoków polityki fiskalnej i pieniężnej w warunkach dwóch skrajnie różnych reżimów kursowych: systemu sztywnego kursu walutowego oraz doskonale płynnego kursu walutowego. Pierwotną siłą napędową mechanizmów opisywanych przez model są międzynarodowe przepływy kapitałowe wywołane różnicami w wartości stóp procentowych w „kraju” i „reszcie świata” wywołane z kolei przez działanie szoków polityki gospodarczej.

Model Mundella-Fleminga liczy sobie już ponad 50 lat (został przedstawiony w 1968 r.), jednak do dziś oś jego rozważań pozostaje aktualna i uważany jest za jedno z doskonalszych narzędzi prezentacji wzajemnych relacji i oddziaływań między gospodarkami różnych krajów w warunkach istnienia handlu zagranicznego i międzynarodowych przepływów kapitałowych. Jako taki jest więc traktowany jako baza do analizowania najbardziej aktualnych zagadnień globalnej ekonomii, zwłaszcza procesów rozprzestrzeniania się na obce kraje efektów polityki makroekonomicznej w warunkach gospodarek otwartych (ale też transmisji szoków gospodarczych, jak nagłe załamania popytu, kryzysy finansowe $)^{42}$.

Model Mundella-Fleminga od początku stanowił punkt wyjścia dla opracowywania nowych ujęć, a co za tym idzie - nowych narzędzi analizy gospodarek otwartych, chociażby przez sam fakt, że w kolejnych koncepcjach - traktując przyjęty schemat modelu jako bazę - rozwijano poszczególne jego elementy, dodawano nowe warunki czy uchylano niektóre założenia ${ }^{43}$. Z punktu widzenia tematyki podjętej w opracowaniu istotne jest, że model podstawowy, tj. jednopodmiotowy, był

42 R.A. Mundell, Capital Mobility and Stabilization Policy Under Fixed and Flexible Exchange Rates, International Economics, Macmillan, New York 1968, s. 250-271.

43 Więcej szczegółów na temat prac nad modelem, jego podstaw teoretycznych i odwołań do innych wcześniejszych koncepcji naukowych w innych opracowaniach autorki. Por. A. Domańska, Odniesienia do modelu Mundella-Fleminga $w$ nowych badaniach na tle ewolucji badań nad transmisją efektów polityki makroekonomicznej między krajami, „Ekonomia - Rynek. Gospodarka. Społeczeństwo” nr 32, Wydawnictwo WNEiZ, Warszawa 2013, s. 54-76; A. Domańska, Nowoczesne modele analizy gospodarki światowej a ewolucja badań nad międzynarodowymi oddziaływaniami krajowej polityki makroekonomicznej, „Ekonomia (Economics)” nr 3(24), Wydawnictwo UE we Wrocławiu, Wrocław 2013, s. 26-43. 
podstawą późniejszych rozwinięć ujmujących w ramy teoretyczne współzależności między dwoma krajami ${ }^{44}$ (schemat dwupodmiotowy, two-country Mundell-Fleming mode ${ }^{45}$ ) z efektami zwrotnymi szoków fiskalnych/pieniężnych, a następnie uogólniany w kierunku uwzględniania większej liczby krajów (modele wielopodmiotowe, tj. międzynarodowe ${ }^{46}$.

Stopniowo rozszerzano więc ramy analityczne mundellowskiego schematu, „otwierając" modelową małą otwartą gospodarkę, będącą źródłem fiskalnego lub monetarnego szoku, na interrelacje z jednym, a następnie $\mathrm{z}$ wieloma krajami. Stworzenie rozszerzonych wersji modelu jest zasługą m.in. R.N. Coopera ${ }^{47}$, R. Dornbuscha $^{48}$, M. Mussy ${ }^{49}$ oraz J.W. McKibbina i J.D. Sachsa ${ }^{50}$.

Najważniejszymi dostrzeżonymi przez innych badaczy niedoskonałościami pierwotnego modelu były: sztywność cen i płac (sprzyjające powstawaniu okresowych nierównowag na rynkach dóbr i czynników produkcji), brak oczekiwań co do zmian kursów walutowych, pełna mobilność kapitału (brak restrykcji i ograniczeń w międzynarodowych przepływach aktywów finansowych).

${ }^{44}$ Względem prostego modelu keynesowskiego otwartej gospodarki dwupodmiotowy model M-F jest rozbudowany, m.in. o uwzględnienie zmian w rachunku kapitałowym bilansu płatniczego. Końcowe efekty uzależnione są od zmian cen, płac i uwarunkowane charakterem indeksacji. Więcej na ten temat zob. A. Domańska, Odniesienia do modelu..., op.cit.

45 Schemat dwupodmiotowy oparty na koncepcji M-F również podlegał zmianom koncepcyjnym. Pewnym rozwinięciem jest tu np. schemat centrum-peryferie (centre-periphery framework), który analizę szoków wynikających z deprecjacji (ekspansywna polityka pieniężna) lub jednostronnej dewaluacji waluty rozszerza na trzy podmioty, umożliwiając jednocześnie wyodrębnienie efektów: dochodowego i cenowego. Współczesne ujęcie schematu centrum-peryferie, przełożone na język zaawansowanych modeli ekonometrycznych, odnajdujemy np. w pracach S. Gerlacha i F. Smetsa oraz G. Corsettiego i P. Pesentiego (model równowagi ogólnej z mikrofundamentami). Por. S. Gerlach, F. Smets, Contangious speculative attacks, „European Journal of Political Economy" 1995, Vol. 11, s. 45-63; G. Corsetti, P. Pesenti, Thesimple geometry of transmission and stabilization in closed and open economies, „NBER Working Paper” May 2005, No. 11341.

46 Por. C.P. Hallwood, R. MacDonald, International Money and Finance, $3^{\text {rd }}$ ed., Wiley-Blackwell, July 2000; C. Betts, M.B. Devreux, The International Effects of Monetary and Fiscal Policy in a Two-country Model, w: Money, Capital Mobility and Trade - Essays in Honour of Robert Mundell, red. G.A. Calvo, R. Dornbusch, M. Obstfeld, MIT Press, Massachusetts 2001.

${ }^{47}$ R.N. Cooper, The economics of interdependence, „The International ExecutiveWiley Periodicals Inc.” 1968, Vol. 10, Issue 4, s. 3-5.

48 R. Dornbusch, Expectations and Exchange Rate Dynamics, „Journal of Political Economics” 1976.

${ }_{49}$ M.L. Mussa, The Exchange Rate, The Balance of Payments and Monetary and Fiscal Policy under the Regime of Controlled Floating, "The Scandinavian Journal of Economics” 1976, No. 2; M. Mussa, Empirical regularities in the behavior of exchange rates and theories of the foreign exchange market, "Carnegie - Rochester Conference Series on Public Policy” 1979, Vol. 11/1, s. 9-57; M. Mussa, The two-sector model in terms of its dual: A geometric exposition, „Journal of International Economics” November 1979, Vol. 9, Issue 4, s. 513-526; M. Mussa, Nominal exchange rate regimes and the behavior of real exchange rates: evidence and implications, „Carnegie - Rochester Conference Series on Public Policy” 1986, 25, s. 117-214.

50 J.W. McKibbin, J.D. Sachs, Global Linkages, Macroeconomic Interdependenceand Cooperation in the World, Brookings Institution Press, Washington, D.C. 1991. 
Koncepcja Mundella-Fleminga empirycznie potwierdza się przede wszystkim w odniesieniu do małych otwartych gospodarek, nie biorąc jednak pod uwagę np. zmian dynamicznych pojawiających się w związku z powstawaniem deficytu i długu publicznego (na skutek ekspansywnej polityki fiskalnej), a w sferze finansowej - w związku z przesunięciami w zasobach zagranicznych aktywów wynikającymi z prowadzenia międzynarodowej wymiany handlowej. Przede wszystkim jednak, o ile koncepcja ta dobrze nadaje się do analizy mechanizmów gospodarczych w bardzo krótkim okresie, to nie uwzględniając średniookresowych procesów dostosowawczych w zakresie ruchów cenowych, nie pokazuje powiązań z zachowaniem gospodarki w okresie długim ${ }^{51}$. Ewolucję modelu Mundella-Fleminga wyznaczają więc modyfikacje wprowadzane do pierwotnego podejścia, które wiązały się ze zbliżaniem jego założeń do realiów współczesnej gospodarki światowej i doprowadziły do znacznego rozszerzenia pierwotnej wersji o nowe aspekty teoretyczne ${ }^{52}$.

Odpowiedzią na ograniczenia analizy wynikające z przyjętej w modelu Mundella-Fleminga (i w ogóle w szkole keynesowskiej) lepkości cen są m.in. odkrycia podejścia monetarnego w ramach nurtu badań wywodzącego się z ekonomii klasycznej, gdzie nacisk położony jest na procesy powolnych dostosowań cenowych do poziomu „klasycznej” równowagi długookresowej ${ }^{53}$. Dlatego w analizach międzynarodowego rozprzestrzeniania się szoków (w tym szoków polityki gospodarczej) odwołujących się do tego podejścia uwaga skupia się również na roli cen produktów i czynników produkcji w sterowaniu mechanizmami przechodzenia (transmisji) gospodarki z powrotem na ścieżkę długookresowego zrównoważonego wzrostu ${ }^{54}$.

Zwolennicy podejścia neokeynesowskiego optowali za rezygnacją z założenia bezwzględnej konkurencji doskonałej. Niedoskonała konkurencyjność i konkurencja monopolistyczna (czy to w odniesieniu do rynków dóbr, czy czynników produkcji) była głównym nowym składnikiem sprowadzonym do modelowania w początkach lat $90 .{ }^{55}$ Analityczne ramy zakładające istnienie konkurencyjności typu monopolistycznego ze sztywnymi cenami nominalnymi i niekompletnymi rynkami aktywów oraz podmiotami podejmującymi decyzje przy ograniczeniach międzyokresowych

${ }^{51}$ A. Domańska, Odniesienia do modelu..., op.cit.

52 Por. A. Adamczyk, R.W. Włodarczyk, Analiza gospodarki otwartej. Model IS-LM-BP, Wydawnictwo AE w Krakowie, Kraków 2006.

${ }^{53}$ Por. np. J.A. Frenkel, H.G. Johnson, The Monetary Approach to the Balance of Payments, University of Toronto Press, Toronto 1976; A. Domańska, Odniesienia do modelu..., op.cit.

54 Por. M. Obstfeld, International Macroeconomics: Beyond the Mundell-Fleming Model, University of California, Berkeley 2000.

55 P. Lane, The New Open Economy Macroeconomics: A Survey, „Trinity Economic Paper Series” 2000, No. 3. 
zaproponowali M. Obstfeld i K. Rogoff ${ }^{56}$. W dwupodmiotowym modelu współzależności międzynarodowych, $\mathrm{w}$ tym transmisji szoków, przedstawionym po raz pierwszy w 1995 r., o nazwie Redux łączą oni odkrycia podejścia międzyokresowego eksplorowane wcześniej m.in. przez J.D. Sachsa ${ }^{57}$ oraz J.A. Frenkela i A. Razina ${ }^{58}$ z twierdzeniami R. Mundella, J.M. Fleminga i R. Dornbuscha (transmisja w warunkach sztywności nominalnych), dołączając mikroekonomiczne podstawy kształtowania się podaży ${ }^{59}$.

W późniejszych rozważaniach teoretycznych weryfikacji poddano również warunek nieograniczonej mobilności kapitału. Rachunek kapitałowy w ujęciu Mundella-Fleminga (pierwotna wersja) jest funkcją poziomów stóp procentowych, co implikuje, że kapitał będzie w sposób swobodny i nieograniczony przepływał z kraju do kraju w sytuacji pojawienia się różnicy poziomów krajowej i zagranicznej stopy procentowej, w rzeczywistości jednak na kształtowanie się salda obrotów kapitałowych wpływa szereg innych czynników np. o charakterze politycznym, psychologicznym, działania spekulacyjne etc. Rozszerzenie analizy na różne poziomy międzynarodowej mobilności kapitału (przy alternatywnych reżimach kursowych) wniosły prace A.K. Swobody ${ }^{60}$, R. Dornbuscha ${ }^{61}$ i M.L. Mussy ${ }^{62}$. R. Dornbusch ${ }^{63}$ doprowadził do przekształcenia warunków statycznych modelu na dynamiczne (dynamika cen oraz dostosowania po stronie produktu), zachowując założenie krótkookresowych sztywności i związanej z nimi niestabilności ${ }^{64}$.

Porównanie krótkookresowych i długookresowych skutków polityki fiskalnej i monetarnej w realiach doskonałej mobilności kapitału wprowadził do rozumowania w schemacie M-F C.A. Rodriguez ${ }^{65}$, a dynamiczny kursu walutowy - M. Obstfeld i A.C. Stockman ${ }^{66}$.

${ }^{56}$ M. Obstfeld, K. Rogoff. Por np. Exchange Rate Dynamics Redux, „Journal of Political Economy” Chicago University Press 1995.

57 J.D. Sachs, The Current Account and Macroeconomic Adjustment in the 1970 s, „Brookings Papers on Economic Activity" 1981, No. 1.

58 J.A. Frenkel, A. Razin, Fiscal Policies and The World Economy: An Intertemporal Approach, MIT Press, Massachusetts 1987.

${ }^{59}$ P. Lane, op.cit., s. 2.

60 A.K. Swoboda, Equilibrium, Quasi-equilibrium and Macroeconomic Policy under Fixed Exchange Rates, "Quarterly Journal of Economics" 1972, Vol. 86.

${ }^{61}$ R. Dornbusch, P. Krugman, Flexible Exchange Rates in the Short Run, „Brookings Papers on Economic Activity" 1976, Vol. 3.

${ }^{62}$ M. Mussa, The two-sector model..., op.cit., s. 513-526; M. Mussa, Nominal exchange..., op.cit., s. $117-214$.

${ }^{63}$ R. Dornbusch, op.cit.

${ }^{64}$ A. Domańska, Odniesienia do modelu..., op.cit.

65 C. Rodriguez, Flexible Exchange Rates and Perfect Capital Mobility, „American Economic Review” 1979, Vol. 69.

${ }^{66}$ A. Adamczyk, R.W. Włodarczyk, op.cit. 


\subsection{Modele analityczne gospodarki otwartej}

Mimo aktualności ujętych w modelu IS-LM praw i zależności, obecnie w analizach makroekonomicznych ściśle odwołujące się do nich metody wyszły z użycia. Początki modelowania, oparte na próbach odwzorowania rzeczywistości według założeń IS-LM, sięgają lat 30. XX w. Najbardziej znanym tego rodzaju narzędziem był - stosowany w latach 1929-1952 do badania gospodarki amerykańskiej - model Kleina-Goldbergera ${ }^{67}$, będący faktycznym ilościowym opisem zależności IS-LM. Późniejsze próby aplikacji tego schematu związane są z wczesnymi pracami nad modelami ekonometrycznymi gospodarek narodowych realizowanymi w latach 40. i 50. w ramach prac tzw. Komisji Cowlesa ${ }^{68}$. Od strony praktycznej ten rodzaj podejścia związany był z posługiwaniem się rozbudowanymi modelami, liczącymi nawet kilka tysięcy równań (dynamicznych, $\mathrm{z}$ reguły liniowych). Modele te miały strukturę blokową (każdy blok odpowiadał modelowaniu zależności między daną grupą zmiennych); bloki te zestawiano w kompletny model gospodarki, a dodatkowo uwzględniano interakcje między zmiennymi wchodzącymi w skład różnych bloków. W ten sposób odwzorowywano całokształt współzależności istniejących $\mathrm{w}$ gospodarce narodowej.

Zgodnie ze schematem IS-LM opartym na paradygmacie keynesowskim modele makroekonometryczne wywodzące się z tradycji Komisji Cowlesa kładły nacisk na kwestie strukturalne, tj. poszukiwanie odpowiednich zmiennych strukturalnych jako regresorów do poszczególnych równań. Modele te umożliwiały oczywiście badanie związków między zmiennymi z uwzględnieniem sprzężeń zwrotnych, ale brały pod uwagę tylko stronę popytową, $\mathrm{z}$ całkowitym pominięciem zagadnienia indywidualnych wyborów podmiotów gospodarczych.

Ogólnie należy stwierdzić, że obecne podejście do analizy gospodarek otwartych i ich wzajemnych oddziaływań stanowi pewną syntezę odkryć dokonanych w badaniach naukowych w ramach różnych szkół i nurtów na przestrzeni ostatnich 50-60 lat. W związku z niedoskonałościami analitycznymi modeli strukturalnych od lat 80. stopniowo rozwija się inne podejście analityczne, wywodzące się ekonomii

${ }^{67}$ Prace nad modelem zainicjowane zostały przez L. Kleina, których celem było ujęcie ilościowe abstrakcyjnych teoretycznych zależności modelu IS-LM. L.R. Klein, Theories of Effective Demand and Employment, "Journal of Political Economy” 1947, Vol. 55, s. 108-131; L.R. Klein, Economic Fluctuations in the United States, 1921-1941, Wiley 1950; L.R. Klein, A. Goldberger, An Econometric Model of the United States, 1929-1952, North Holland, Lucas and Rapping 1955; L.R. Klein, The Empirical Foundations of Keynesian Economics, w: Post Keynesian Economics, red. K.K. Kurihara, Rutgers University Press 1954, s. 277-319.

${ }^{68}$ Komisja Cowlesa rozpoczęła swoją działalność w 1939r. w Chicago. W jej skład weszli zwolennicy teorii konkurencji niedoskonałej i keynesizmu. Czołową postacią chicagowskiej szkoły w ekonomii 1938-1945 był polski ekonomista O. Lange. 
klasycznej w ogóle, a dokładniej związane z odkryciami nowej ekonomii klasycznej. Chodzi mianowicie o modele równowagi ogólnej (General Structural Equilibrium Models, GEMs). Nowoklasyczna szkoła ekonomii, której założycielami byli w latach 80. R. Lucas, T. Sargent i N. Wallace ${ }^{69}$, postulowała ciągłą (odnawiającą się) równowagę rynków, istnienie racjonalnych oczekiwań, dokonywanie przez podmioty międzyokresowej optymalizacji jeśli chodzi o wybory dotyczące konsumpcji i produkcji, asymetrię informacji ${ }^{70}$.

Od strony metodologicznej w dzisiejszych badaniach oprócz modeli równowagi ogólnej stosuje się najczęściej autoregresyjne metody analizy wektorowej ${ }^{71}$.

Najbardziej rozwiniętą formą tego podejścia analitycznego i dlatego szeroko stosowaną przez instytucje, takie jak banki centralne ${ }^{72}$, IMF, instytuty badawcze przy OECD, UE etc., są stochastyczne dynamiczne modele równowagi ogólnej (Dynamic Stochastic General Equilibrium Models, DSGE). Jak ujmuje to G. Grabek, „Modele DSGE dają szansę strukturalnego (wewnętrznie spójnego, odwołującego się do zachowań podmiotów opisywanych na poziomie mikro) wyjaśnienia przyczyn [...] zjawisk i ich konsekwencji.

Modele DSGE przedstawiają odmienny niż klasyczne modele makroekonometryczne obraz procesów gospodarczych - widzą świat przez pryzmat zaburzeń strukturalnych. Zaburzenia te wprawiają gospodarkę w ruch, a podmioty gospodarcze optymalnie reagują na nie, prowadząc do eliminacji ich skutków, tzn. powracając do równowagi”’3. Według A. Bezata i innych łączą one „z jednej strony kompleksowość zdarzeń gospodarczych, a z drugiej ich dynamikę i stochastyczny charakter. W wykorzystaniu modeli tego typu dostrzega się szanse nie tylko na stosunkowo trafne ujęcie zależności występujących w gospodarce, lecz również bliskie rzeczywistości symulowanie potencjalnych skutków wywołanych działaniem różnych czynników sprawczych,

69 Za: V.V. Chari, Nobel Laureate Robert E. Lucas, Jr: Architect of Modern Macroeconomics, „Journal of Economic Perspectives" Winter 1998, Vol. 12, No. 1, s. 171-186.

70 Por. A. Domańska, Odniesienia do modelu..., op.cit.; A. Domańska, Nowoczesne modele..., op.cit.

71 Prezentacji modeli autoregresji wektorowej (vector autoregression models, VARs) autorka poświęciła sporo miejsca w innym swoim opracowaniu, w związku z czym w tym miejscu ten wątek nie będzie rozwijany. Por. A. Domańska, Synchronizacja cykli koniunkturalnych - wybrane zagadnienia metody analizy empirycznej, „Optimum Studia Ekonomiczne” nr 3(63), Wydział Ekonomii i Zarządzania Uniwersytetu w Białymstoku, Wydawnictwo UE w Białymstoku, Białystok 2013, s. 58-77.

72 Modele typu DSGE (tzw. SOE PL) i SOE PL-2009 od początku 2010 r. stosowane są przez Narodowy Bank Polski do budowania rutynowych, średniookresowych prognoz procesów inflacyjnych oraz koniunktury gospodarczej, uzupełniając tradycyjnie stosowany wcześniej strukturalny model makroekonometryczny oraz prognozy eksperckie. Jest to praktyka stosowana coraz powszechniej przez wiele banków centralnych, jak model Riksbanku strefy euro.

73 G. Grabek, B. Kłos, G. Koloch, SOE PL-2009 - Model DSGE małej otwartej gospodarki estymowany na polskich danych. Specyfikacja, oceny parametrów, zastosowania, „Materiały i Studia NBP” 2010, nr 251, s. 7. 
między innymi instrumentów polityki gospodarczej"74. Nie sposób wymienić choć części badań opierających się na każdej z metod, gdyż de facto są ich setki.

Zastosowanie modeli równowagi ogólnej do analizy aktualnych problemów zarówno w obrębie gospodarek otwartych, jak i ich międzynarodowych współzależności to temat obejmujący swoją szerokością większość współczesnego dorobku badawczego w zakresie makroekonomii gospodarki otwartej. Wykorzystanie tej metody analitycznej (również w wersji dynamicznej, tj. dynamiczne stochastyczne modele równowagi ogólnej, Dynamic Stochastic General Equilibrium) stanowi bazę do, wychodzącego od mikroekonomicznych założeń optymalizacji decyzji, badania bardzo wielu zagadnień gospodarki otwartej w zakresie wszystkich rynków na poziomie relacji między przedsiębiorstwami, w przekroju branż, sektorów i rynków, wreszcie między krajami, regionami i w skali globalnej. W tym analizuje się tą metodą skutki - wewnętrzne, ale i międzynarodowe efektów polityki fiskalnej i pieniężnej. Nie jest więc możliwe przedstawienie w niniejszym krótkim opracowaniu szczegółów metody czy dokonanie pobieżnego chociażby przeglądu literatury naukowej wykorzystującej to podejście.

Ograniczę się więc do wymienienia wybranych modeli „globalnych"75 o tyle interesujących, że stanowią próbę makroekonomicznej analizy gospodarki świata jako całości. Jednocześnie studia realizowane w ramach modeli globalnych uwzględniają również tradycyjne podejście, tj. stosowanie analizy regresyjnej i badania zależności korelacyjnych pomiędzy różnymi danymi makroekonomicznymi, wykorzystując głównie analizę szeregów czasowych. Mają przy tym charakter prognostyczny, tj. umożliwiają prognozowanie sytuacji gospodarczej w analizowanych krajach (regionach) w różnych branych pod uwagę scenariuszach (związanych z pojawieniem się np. szoków cenowych o znaczeniu globalnym, ze zmianami w polityce fiskalnej czy monetarnej w państwach o kluczowym znaczeniu dla gospodarki świata, jak USA, strefa euro czy Chiny). Modele te operują na zagregowanych danych statystycznych, pozwalając jednocześnie na analizę bardziej szczegółową (np. badając relacje między wielkością produkcji, zatrudnienia, inwestycji i innych zmiennych w różnych branżach). Z reguły mają one charakter blokowy i składają z setek lub tysięcy równań opisujących ewolucję setek lub tysięcy cen i ilości w czasie. Wybór zmiennych, które używane są w takich równaniach, częściowo kierowany jest przez teorię ekonomii (np. dochód jako czynnik wpływający na konsumpcję, jak sugeruje teoria adaptacyjnych oczekiwań), ale wiele z tych zmiennych jest określana głównie czysto empiryczne.

${ }^{74}$ A. Bezat, Sz. Figiel, J. Kufel, Model stochastycznego dynamicznego modelu równowagi ogólnej jako narzędzie wspierające formułowanie założeń polityki rolnej. Synteza wyników badań prowadzonych w latach 2008-2009, Instytut Ekonomiki Rolnictwa i Gospodarki Żywnościowej, Warszawa 2009, s. 7.

75 Szczegółowo autorka omówiła te modele w innej swojej publikacji, tj. A. Domańska, Nowoczesne modele..., op.cit., s. 26-43. 
Modelem, który otworzył nowe pole w analizach empirycznych, wyznaczane modelowaniem równowagi ogólnej z dopracowanymi mikropodstawami równań poszczególnych rynków, był tzw. Redux. Autorami tego modelu, przedstawionego po raz pierwszy w 1995 r., są M. Obstfeld i K. Rogoff ${ }^{76}$. Redux prezentuje współzależności międzynarodowe w ujęciu dwupodmiotowym, łącząc odkrycia podejścia międzyokresowego eksplorowane wcześniej m.in. przez J.D. Sachsa ${ }^{77}$ oraz J.A. Frenkela i A. Razina ${ }^{78} \mathrm{z}$ twierdzeniami R. Mundella, J.M. Fleminga i R. Dorbuscha (transmisja w warunkach sztywności nominalnych) i dołączając mikroekonomiczne podstawy kształtowania się podaży. Pierwszy globalny model makroekonomiczny - LINK (Wharton Econometric Forecasting Associates) - został zainicjowany przez L. Kleina. Kolejnym, bardzo ważnym modelem i jednym z pierwszych prezentujących rzeczywistość gospodarczą w schemacie równowagi ogólnej (w ujęciu dynamicznym) był opracowany przez McKibbena i Sachsa w 1991 r. ${ }^{79}$ tzw. McKibben-Sachs global model (MSG, późniejsza wersja to MSG2). Jest on też niejako wstępem do późniejszych „blokowych” modeli gospodarki światowej.

Jednym z pierwszych modeli globalnych bazujących na podejściu równowagi ogólnej jest opracowany w późnych latach 80. i wykorzystywany przez OECD INTER$L_{I N K}{ }^{80}$. Ważnym modelem gospodarki światowej jest też Multimod ${ }^{81}$. Po raz pierwszy opracowany i udokumentowany empirycznie przez Massona i innych w 1998 r., został on następnie rozwinięty i udoskonalony w kierunku uwzględnienia całego zespołu międzynarodowych powiązań między krajami w celu wspomagania działań doradczych IMF. Wnioski analiz realizowanych na podstawie Multimod szeroko wykorzystywane i opisywane są w World Economic Outlook - wydawanym dwa razy w roku przez IMF kompleksowym raporcie na temat gospodarki światowej.

Najnowszym modelem „globalnym” jest tzw. New Global Model ${ }^{82}$, będący kontynuacją INTERLINK jeśli chodzi o instrumentarium analiz globalnych OECD.

${ }^{76}$ Por. np. M. Obstfeld, K. Rogoff, op.cit.

77 J.D. Sachs, op.cit.

78 J.A. Frenkel, A. Razin, op.cit.

79 J.W. McKibbin, J.D. Sachs, op.cit.

80 Por. np. The OECD international linkage model, „OECD Economic Outlook Occasional Studies” January 1979; OECD INTERLINK System Operations Manual, December 1984; The OECD lNTERLINK System, January 1981; F. Larsen, J. Llewellyn, S. Potter, International economic linkages, „OECD Economic Studies” Autumn 1983, No. 1; J. Llewellyn, P. Richardson, Representing recent policy concerns in INTERLINK, „OECD Economic Studies" Autumn 1985, No. 5; P. Richardson, Recent developments in OECD's international macroeconomic model, OECD 1987; P. Richardson, A review of the simulation properties of OECD's INTERLINK model, OECD 1987.

${ }^{81}$ D. Laxton, P. Isard, H. Faruquee, E. Prasad, B. Turtelboom, Multimod Mark III, The Core Dynamic and Steady-State Models, IMF, May 1998.

${ }^{82}$ K. Herve, N. Pain, P. Richardson, F. Sedillot, P.O. Beffy, The OECD’s New Global Model, „OECD Economics Department Working Papers" 2010, No. 768. 
New Global Model jest wykorzystywany do badania oraz prognozowania szerokiego spektrum makroekonomicznych problemów współczesnego świata, ze szczególnym uwzględnieniem skutków międzynarodowych powiązań finansowych oraz rozprzestrzeniania skutków polityki fiskalnej i monetarnej. Został on wprowadzony do prac analitycznych w połowie zeszłej dekady i służy aktualnie do opracowywania wniosków i scenariuszy publikowanych w oficjalnych raportach tej organizacji, takich jak OECD Global Outlook, nie wyłączając najnowszych raportów ${ }^{83}$.

\section{Podsumowanie i wnioski}

Niniejsze opracowanie zostało poświęcone zagadnieniom szoków polityki fiskalnej i pieniężnej w warunkach otwartości gospodarek. Jest to temat bardzo rozległy, pokrywający w zasadzie większą część problematyki analizowanej w ramach makroekonomii gospodarki otwartej. Współcześnie polityka gospodarcza funkcjonuje bowiem immanentnie w warunkach intensywnej współpracy międzynarodowej i wzajemnej współzależności rynków, podlega wpływom zewnętrznym związanym z liberalizacją obrotów w handlu towarami i usługami, globalizacją rynków finansowych, międzynarodowym przepływem kapitału, osób i informacji. Jednym z aspektów tego zagadnienia jest podleganie polityki wpływom szoków i kryzysów gospodarczych o charakterze regionalnym lub globalnym.

W związku z tym w założeniach niewielkiej objętościowo pracy możliwe było bardzo ogólne zarysowanie tematu, z uwypukleniem kilku jego wybranych aspektów. Wychodząc od definiowania i w ogóle rozumienia w literaturze terminów „szok polityki fiskalnej” i „szok polityki pieniężnej”, przedstawiłam pokrótce modele stanowiące podstawę badania efektów tej polityki w warunkach otwartości gospodarek. Mianowicie odniosłam się do modelu IS-LM, modelu małej otwartej gospodarki oraz do modelu Mundella-Fleminga (M-F), który stanowił istotny punkt zwrotny w badaniu przenoszenia efektów polityki makroekonomicznej między krajami.

Następnie, wychodząc od modelu M-F, starałam się skrótowo pokazać przebieg ewolucji, która dokonała się w badaniu międzynarodowych efektów szoków polityki fiskalnej i pieniężnej - w sensie koncepcyjnym (tj. nowe ujęcia, nowe założenia uzupełniające podstawowy schemat), ale też aplikacyjnym (wpisywanie go do nowoczesnych narzędzi analitycznych, przechodzenie od ujęcia statycznego do metod dynamicznych itp.). Pokrótce przedstawiłam podejście metodologiczne stosowane

83 Więcej zob. A. Domańska, Nowoczesne modele..., op.cit. 
$\mathrm{w}$ dzisiejszych badaniach, tj. autoregresyjne modele dynamiczne (VAR) oraz modele równowagi ogólnej. Wymieniłam też blokowe modele służące badaniu i prognozowaniu rozwoju gospodarki światowej, takie jak McKibben-Sachs Global model (MSG), Redux, a także Multimod opracowany i stosowany przez Międzynarodowy Fundusz Walutowy (IMF), INTERLINK OECD (lata 80. i 90.), czy New Global Model OECD (pierwsza dekada XXI w. i obecnie).

Według mnie rysują się trzy zasadnicze aspekty uwarunkowania polityki fiskalnej i pieniężnej faktem transgranicznej transmisji impulsów (szoków) makroekonomicznych. Po pierwsze, polityka w kraju otwartym na zagraniczne impulsy koniunkturalne musi per se bezpośrednio wynikać, albo też być reakcją na sytuację ukształtowaną również wpływem czynników zewnętrznych (np. reagowanie państwa na regionalne czy globalne załamania gospodarcze, których skutkiem z reguły jest pogorszenie bilansów wynikowych gospodarki krajowej). Po drugie, efekty szoków polityki fiskalnej i pieniężnej podlegają działaniu, zmianom (wzmocnieniu/osłabieniu) w związku z samą otwartością rynku krajowego na resztę świata. Po trzecie, w realiach „naczyń połączonych", jakimi coraz bardziej stają się krajowe organizmy gospodarcze, efekty polityki makroekonomicznej (zwłaszcza rzecz jasna krajów dużych mających wpływ na globalne wskaźniki aktywności gospodarczej) często „rozlewają się" różnymi kanałami na inne kraje. Chodzi więc o swego rodzaju „wyciek” tych efektów za granicę (dostrzegany i szacowany ilościowo w modelach globalnych IMF czy OECD). $\mathrm{W}$ dalszej kolejności natomiast pojawiają się ze strony gospodarek przyjmujących ten wpływ efekty zwrotne - a więc transmisja impulsu (szoku) polityki fiskalnej lub pieniężnej rodzi różnego rodzaju efekty pośrednie „wracające” do źródła szoku. Jest to ważki problem z punktu widzenia projektowanej zasadności i skuteczności różnych narzędzi polityki gospodarczej prowadzonej przez rządy i władze monetarne w dzisiejszym świecie.

\section{Fiscal and monetary policy shocks as the subject of studies of open economy macroeconomics}

The aim of this study is to present selected aspects of fiscal and monetary policy shocks as the subject of studies of open economy macroeconomics. The study concentrates on the development of the model presentation (evolution of the research method) in description of fiscal and monetary policy shocks, with a focus on the modern quantitative approach. At present the modern approach to the research on fiscal and monetary policy shocks is based on advanced methods 
of data analyzing, such as autoregressive models (VAR), or stochastic dynamic general equilibrium models (DSGE).

Keywords: fiscal shocks, monetary shocks, transmission of economic shocks, macroeconomics of open economies, quantitative methods

\section{Les chocs de la politique budgétaire et monétaire comme sujet d'études macroéconomiques en économie ouverte}

Le but de cette article est de présenter certains aspects des chocs de la politique budgétaire et monétaire comme sujet d'études macroéconomiques en économie ouverte. L'article se concentre sur le développement de la présentation du modèle (évolution de la méthode de recherche) dans la description des chocs politiques budgétaires et monétaires, en s'appuyant sur l'approche quantitative moderne. Actuellement, l'approche moderne de recherche sur ces chocs est basé sur des méthodes avancées de l'analyse de données, telles que les modèles autorégressifs ou les modèles d'équilibre général dynamique et stochastique.

Mots-clés: les chocs budgétaires, les chocs monétaires, la transmission des chocs économiques, la macroéconomie des économies ouvertes, les méthodes quantitatives

\section{Шоки фискальной и монетарной политик как предмет изучения макроэкономики открытой экономики}

Целью данной работы является представление отдельных аспектов шоков фискальной и денежно-кредитной политик как предмета изучения макроэкономики открытой экономики. Исследование сконцентрировано на развитии модельного подхода в описании шоков налогово-бюджетной и денежно-кредитной политик, с особым упором на современные количественные подходы. В настоящее время современный подход к изучению шоков налогово-бюджетной и денежно-кредитной политик основывается на продвинутых методах анализа данных, таких как модели авторегрессии (VAR) или динамические стохастические модели общего равновесия (DSGE).

Ключевые слова: финансовые шоки, денежные шоки, передача экономических шоков, макроэкономика открытой экономики, количественные методы 